\title{
Synthesis of Benzyl
}

\section{4-Hydroxy-5-iodo-2,3-dimethoxy-6-methylbenzoate - The Aromatic Unit of Calicheamicin $\gamma_{1}{ }^{\mathrm{I}}$}

\author{
Elson Santiago de Alvarenga ${ }^{\mathrm{a}}{ }$, and John Mann ${ }^{\mathrm{b}}$ \\ ${ }^{a}$ Departamento de Química, Universidade Federal de Viçosa \\ 36571-000 Viçosa - Minas Gerais, Brazil \\ ${ }^{\mathrm{b}}$ Chemistry Department, Reading University, Whiteknights, Reading, \\ RG6 6AD, England
}

\begin{abstract}
Ácido orselínico é benzilado e 4-benziloxi-2-hidroxi-6-metilbenzoato de benzila (7) é então convertido no composto desejado (2), o qual é o constituinte aromático de calicheamicin $\gamma_{1}$ I.

Orsellinic acid (6) was benzylated, and the benzyl 4-benzyloxy-2-hydroxy-6-methylbenzoate (7) was then elaborated into the title compound (2), which is the aromatic constituent of calicheami$\operatorname{cin} \gamma_{1} \mathrm{I}$.
\end{abstract}

Keywords: calicheamicin $\gamma_{1}^{I}$, antitumour, orsellinic acid

\section{Introduction}

Calicheamicin $\gamma_{1}{ }^{\mathrm{I}}$ is a highly sophisticated molecule that displays high antitumour and antibiotic potency and an unusual mode of action ${ }^{1}$.

Nicolaou et al. ${ }^{2}$ used compound (1) as an intermediate in the synthesis of calicheamicin $\gamma_{1}$. Nevertheless after coupling the monossacaride to the free hydroxyl of (1), they needed three steps to convert the methyl ester into the corresponding carboxylic acid.

In this work we describe the synthesis of benzyl 4-hydroxy-5-iodo-2,3-dimethoxy-6-methylbenzoate (2) from the readily available 3,5-dimethoxytoluene (3).

The benzyl ester (2) should be a better intermediate for the synthesis of calicheamicin $\gamma_{1}{ }^{\mathrm{I}}$ than the methyl ester (1), as the benzyl group can be easily removed by hydrogenation without deprotecting the carbohydrate bound to the free oxygen.

\section{Experimental}

Reagents and solvents were purified when necessary according to the usual procedures described in the literature $^{3}$. Flash column chromatography was performed using Crosfield Sorbil C60 (32-63 $\mu \mathrm{m})$. Rfs were determined by Analytical Thin Layer Chromatography on a $0.25 \mathrm{~mm}$ film of silica gel containing fluorescent indicator $\mathrm{UV}_{254}$ sup- ported on a plastic sheet (CamLab plc.). The melting points were determined on an Electrothermal digital apparatus without correction. Infrared Spectra were recorded on a Perkin Elmer 881 grating spectrometer, scanning from 625 to $4000 \mathrm{~cm}^{-1}$. The samples were run as nujol mull. Mass Spectra were recorded on a MICROMASS 7070F. ${ }^{1} \mathrm{H}$ and ${ }^{13} \mathrm{C}$-NMR spectra were recorded on a JEOL JNM-EX400 (400 and 100.53 MHz) and on a Bruker WH250 (250 and $62.89 \mathrm{MHz}$ ). They were recorded in $\mathrm{CDCl}_{3}$ and tetramethylsilane was used as the internal standard.

\section{Benzyl 4-benzyloxy-2-hydroxy-6-methylbenzoate (7) and Benzyl 2,4-dibenzyloxy-6-methylbenzoate (8)}

To a mixture of orsellinic acid (6) (5.0 g, 29.7 mmoles) and anhydrous potassium carbonate $(15.0 \mathrm{~g}, 108.5$ mmoles $)$ in dry acetone $(150 \mathrm{~mL})$ was added benzyl bromide (14.0 $\mathrm{g}, 81.9$ mmoles). The mixture was stirred under reflux in an atmosphere of argon for $7 \mathrm{~h}$. The heating was removed and the mixture was poured into $2 \mathrm{M}$ hydrochloric acid (500 $\mathrm{mL})$. The mixture was extracted with petrol-diethyl ether 4:6 $(4 \times 200 \mathrm{~mL})$ and the combined organic layers dried $\left(\mathrm{MgSO}_{4}\right)$, filtered and evaporated to dryness. The white crystalline residue was mixed with silica gel and purified by column chromatography eluting with petrol-diethyl ether 8:2. The dibenzyl compound was obtained as white 
crystalline needles (4.3 g, MW 348.398, 42\%) and the tribenzyl as white crystalline plates $(7.6 \mathrm{~g}, 58 \%)$.

\section{Compound 7}

$\mathbf{R}_{\mathbf{f}} 0.49$ (petrol-diethyl ether 8:2); m.p. $78^{\circ} \mathrm{C} ; \delta_{\mathrm{H}}(250$ $\mathrm{MHz} ; \mathrm{CDCl}_{3} ; \mathrm{J} / \mathrm{Hz}$ ) 2.49 (s, $3 \mathrm{H}, \mathrm{ArCH}_{3}$ ), 5.05 (s, $2 \mathrm{H}, \mathrm{CH}_{2}$, $\mathrm{Bn}), 5.38$ (s, $\left.2 \mathrm{H}, \mathrm{CH}_{2}, \mathrm{Bn}\right), 6.30-6.45$ (m, $\left.2 \mathrm{H}, \mathrm{ArH}\right)$, 7.30-7.50 (m, $10 \mathrm{H}, 2$ x Bn); $\delta_{\mathrm{C}}\left(62.9 \mathrm{MHz} ; \mathrm{CDCl}_{3}\right) 24.6$ $\left(\mathrm{ArCH}_{3}\right), 67.0\left(\mathrm{CH}_{2}\right), 69.9\left(\mathrm{CH}_{2}\right), 99.8,111.8(\mathrm{C}-3,-5)$, 127.4, 128.1, 128.4, 128.6 (Bn), 135.4 (C-1, Bn), 136.2 (C-1, Bn), 143.2 (C-6), 163.1, 165.6 (C-2, -4), 171.4 $(\mathrm{C}=\mathrm{O})$; (found: $348.1353 . \mathrm{C}_{22} \mathrm{H}_{20} \mathrm{O}_{4}$ requires, 348.1362).

\section{Compound $\mathbf{8}$}

$\mathbf{R}_{\mathbf{f}} 0.31$ (petrol-diethyl ether 8:2); m.p. $93{ }^{\circ} \mathrm{C} ; \delta_{\mathrm{H}}(250$ $\mathrm{MHz} ; \mathrm{CDCl}_{3} ; \mathrm{J} / \mathrm{Hz}$ ) 2.25 (s, $\left.3 \mathrm{H}, \mathrm{ArCH}_{3}\right), 5.00$ (s, $2 \mathrm{H}, \mathrm{CH}_{2}$, $\mathrm{Bn}), 5.02$ (s, $\left.2 \mathrm{H}, \mathrm{CH}_{2}, \mathrm{Bn}\right), 5.30\left(\mathrm{~s}, 2 \mathrm{H}, \mathrm{CH}_{2}, \mathrm{Bn}\right)$, 6.35-6.45 (m, $2 \mathrm{H}, \mathrm{ArH})$, 7.25-7.45 (m, $15 \mathrm{H}, 3$ x Bn); $\delta_{\mathrm{C}}\left(62.9 \mathrm{MHz} ; \mathrm{CDCl}_{3}\right) 19.9\left(\mathrm{ArCH}_{3}\right), 66.7\left(\mathrm{CH}_{2}\right), 70.0$ $\left(\mathrm{CH}_{2}\right), 70.4\left(\mathrm{CH}_{2}\right), 98.4,108.2(\mathrm{C}-3,-5), 117.1,127.0$, 127.3, 127.7, 128.0, 128.3, 128.4, $128.5(\mathrm{Bn}), 135.9$, 136.5, 136.6 (3 x CH $2, \mathrm{Bn}), 138.4$ (C-6), 157.3, 160.4 (C-2, -4), $167.9(\mathrm{C}=\mathrm{O})$.

Benzyl 4-benzyloxy-2-hydroxy-3-formyl-6methylbenzoate (9)

A 1.0 M dichloromethane solution of titanium (IV) chloride ( $75 \mathrm{~mL}, 75$ mmoles) was added dropwise to a vigorously stirred cooled $\left(-10{ }^{\circ} \mathrm{C}\right)$ solution of the dibenzyl (7) (10.37 g, 29.8 mmoles) and dichloromethyl methyl ether $^{\#}$ (7.5 g, 65.2 mmoles) in dry dichloromethane (150 $\mathrm{mL}$ ) under argon atmosphere. Stirring was continued for a further $3 \mathrm{~h}$ at $0{ }^{\circ} \mathrm{C}$, and then poured into ice-cold hydrochloric acid $(500 \mathrm{~mL})$. The resulting suspension was transferred to a separating funnel and the layers separated. The aqueous layer was extracted with diethyl ether-petrol 6:4 ( $3 \times 350 \mathrm{~mL}$ ). The dichloromethane was evaporated under vacuum and the residue was combined with the ether-petrol layers. The organic mixture was washed with water $(2 \mathrm{x}$ $100 \mathrm{~mL})$, filtered through a pad of silica gel, and the silica washed with diethyl ether $(500 \mathrm{~mL})$. The solvent was removed on the rotary evaporator and the residue dried under high vacuum to give a red solid which was used without any further purification $(10.0 \mathrm{~g}, 89 \%)$.

$\mathbf{R}_{\mathbf{f}} 0.27$ (petrol-diethyl ether 6:4); $\mathrm{v}$ (nujol mull) $/ \mathrm{cm}^{-1}$ $1727(\mathrm{C}=\mathrm{O}$, ester $)$ and $1637\left(\mathrm{C}=\mathrm{O}\right.$, aldehyde); $\delta_{\mathrm{H}}(250$ $\mathrm{MHz} ; \mathrm{CDCl}_{3} ; \mathrm{J} / \mathrm{Hz}$ ) 2.32 (s, $\left.3 \mathrm{H}, \mathrm{ArCH}_{3}\right), 5.15$ (s, $2 \mathrm{H}, \mathrm{CH}_{2}$, $\mathrm{Bn}), 5.38$ (s, $\left.2 \mathrm{H}, \mathrm{CH}_{2}, \mathrm{Bn}\right), 6.30$ (s, $\left.1 \mathrm{H}, \mathrm{ArH}\right), 7.30-7.50$ (m, $10 \mathrm{H}, \mathrm{Bn}), 10.30$ (s, $1 \mathrm{H}, \mathrm{CHO})$.

\section{Benzyl 4-benzyloxy-2,3-dihydroxy-6-methylbenzoate (10)}

A solution of the aldehyde (9) (9.5 g, 25.2mmoles) in a mixture of dioxane $(150 \mathrm{~mL})$ and $40 \%$ sodium hydroxide

\footnotetext{
\# Dichloromethyl methyl ether is highly toxic lachrymator
}

(7 mL) was stirred and cooled in an ice bath under argon atmosphere. Hydrogen peroxide $(30 \%, 60 \mathrm{~mL})$ in dioxane $(120 \mathrm{~mL})$ was added dropwise using a pressure equalizer dropping funnel. The cooling bath was removed and after stirring for a further $1 \mathrm{~h}$ the solution was poured into ice-cold $2 \mathrm{M}$ hydrochloric acid $(250 \mathrm{~mL})$ and extracted with diethyl ether ( $3 \times 200 \mathrm{~mL})$. The combined ether layers were washed with water $(2 \times 100 \mathrm{~mL})$ and brine $(2 \times 100 \mathrm{~mL})$ and dried $\left(\mathrm{MgSO}_{4}\right)$. The solvent was removed and the oily residue filtered through a pad of silica gel to give a yellow oil $(8.8 \mathrm{~g}, 96 \%)$.

$\mathbf{R}_{\mathbf{f}} 0.27$ (petrol-diethyl ether 6:4); $v$ (nujol mull) $/ \mathrm{cm}^{-1}$ $3469(\mathrm{OH}), 1653(\mathrm{C}=\mathrm{O}) ; \delta_{\mathrm{H}}\left(250 \mathrm{MHz} ; \mathrm{CDCl}_{3} ; \mathrm{J} / \mathrm{Hz}\right) 2.45$ (s, $3 \mathrm{H}, \mathrm{ArCH}_{3}$ ), 5.18 (s, $\left.2 \mathrm{H}, \mathrm{CH}_{2}, \mathrm{Bn}\right), 5.40$ (s, $2 \mathrm{H}, \mathrm{CH}_{2}$ ), 5.45 (s, $1 \mathrm{H}, \mathrm{OH}), 6.35$ (s, 1 H, ArH), 7.30-7.50 (m, $10 \mathrm{H}$, $2 \times \mathrm{Bn})$.

Benzyl 4-benzyloxy-2,3-dimethoxy-6-methylbenzoate (11)

A mixture of potassium carbonate $(14.0 \mathrm{~g}, 102.8 \mathrm{mmo}-$ les), the catechol (10) (8.6 g, 23.6mmoles) and dimethyl sulphate $(10.0 \mathrm{~g}, 79.3 \mathrm{mmoles})$ in dry acetone $(250 \mathrm{~mL})$ was refluxed for $5 \mathrm{~h}$ under argon atmosphere. The heating was removed and after $10 \mathrm{~min}$ it was filtered under vacuum using a sinter funnel and the solid was washed with acetone. The filtrate was evaporated to dryness in the rotary evaporator and the residue was dissolved in diethyl ether-petrol 2:8. The solution was loaded onto a column with silica gel and eluted with the same solvent mixture to give the title compound as a crystalline solid $(7.7 \mathrm{~g}, 83 \%)$.

$\mathbf{R}_{\mathbf{f}} 0.51$ (petrol-diethyl ether 6:4); $\delta_{\mathrm{H}}\left(250 \mathrm{MHz} ; \mathrm{CDCl}_{3}\right.$; $\mathrm{J} / \mathrm{Hz}) 2.20$ (s, $\left.3 \mathrm{H}, \mathrm{ArCH}_{3}\right), 3.84,3.86$ (2s, 2 x $3 \mathrm{H}, 2$ x $\left.\mathrm{OCH}_{3}\right), 5.10$ (s, $2 \mathrm{H}, \mathrm{CH}_{2}, \mathrm{Bn}$ ), 5.35 (s, $2 \mathrm{H}, \mathrm{CH}_{2}, \mathrm{Bn}$ ), 6.50 (s, $1 \mathrm{H}, \mathrm{ArH}), 7.30-7.50$ (m, $10 \mathrm{H}, 2 \mathrm{x} \mathrm{Bn}$ ); (found: 392.1602. $\mathrm{C}_{24} \mathrm{H}_{24} \mathrm{O}_{5}$ requires, 392.1624).

\section{4-Hydroxy-2,3-dimethoxy-6-methylbenzoic acid (12)}

A mixture of the dibenzyl (11) (4.5 g, 11.5 mmoles) and $5 \%$ palladium on carbon $(0.7)$ in ethyl acetate $(100 \mathrm{~mL})$ under an atmosphere of hydrogen was stirred overnight. The mixture was filtered and the palladium washed with ethyl acetate. The combined organic washings were evaporated under vacuum to give a yellow oil (2.33 g, 96\%).

$\mathbf{R}_{\mathbf{f}} 0.10$ (petrol-diethyl ether 6:4); $\delta_{\mathrm{H}}\left(250 \mathrm{MHz} ; \mathrm{CDCl}_{3}\right.$; $\mathrm{J} / \mathrm{Hz}) 2.25$ (s, $\left.3 \mathrm{H}, \mathrm{ArCH}_{3}\right), 3.80,3.88$ (2s, 2 x $3 \mathrm{H}, 2$ x $\left.\mathrm{OCH}_{3}\right), 6.54$ (s, $\left.1 \mathrm{H}, \mathrm{OH}\right), 8.28$ (broad s, $\left.1 \mathrm{H}, \mathrm{OH}\right)$. 
Benzyl 4-hydroxy-2,3-dimethoxy-6-methylbenzoate (13)

A mixture of the acid-phenol (12) $(0.48 \mathrm{~g}, 2.26 \mathrm{mmo}-$ les), anhydrous potassium carbonate $(0.40 \mathrm{~g}, 2.89$ mmoles $)$ and benzyl bromide ( $0.40 \mathrm{~g}, 2.34$ mmoles) in dry acetone $(20 \mathrm{~mL})$ was stirred overnight at room temperature under argon atmosphere. The mixture was poured into ice cold 2 $\mathrm{M}$ hydrochloric acid $(40 \mathrm{~mL})$ and was extracted with diethyl ether $(3 \times 50 \mathrm{~mL})$. The combined organic layers were washed with water $(2 \times 50 \mathrm{~mL})$ and brine $(1 \times 50 \mathrm{~mL})$ and dried $\left(\mathrm{MgSO}_{4}\right)$. The ether was removed under vacuum and the residue purified by column chromatography eluting with petrol-diethyl ether 7:3 to give the benzyl ester as an oil $(0.15 \mathrm{~g}, 22 \%)$.

$\mathbf{R}_{\mathbf{f}} 0.30$ (petrol-diethyl ether 6:4); $\delta_{\mathrm{H}}\left(250 \mathrm{MHz} ; \mathrm{CDCl}_{3}\right.$; $\mathrm{J} / \mathrm{Hz}) 2.20\left(\mathrm{~s}, 3 \mathrm{H}, \mathrm{ArCH}_{3}\right), 3.79,3.87$ (2s, 2 x $3 \mathrm{H}, 2$ x $\mathrm{OCH}_{3}$ ), 5.35 (s, 2H, CH $\left.2, \mathrm{Bn}\right), 5.92$ (s, 1 H, OH), 6.54 (s, 1H, ArH), 7.33-7.46 (m, $5 \mathrm{H}, \mathrm{ArH}, \mathrm{Bn}) . \delta_{\mathrm{C}}(100 \mathrm{MHz}$; $\left.\mathrm{CDCl}_{3}\right) 19.4\left(\mathrm{ArCH}_{3}\right), 60.8,61.2\left(2 \mathrm{x} \mathrm{OCH}_{3}\right), 67.0$ $\left(\mathrm{CO}_{2} \mathrm{CH}_{2}\right), 112.4$ (C-5), 120.5 (C-1), 128.3, 128.5, 128.6 (Bn, o, m, p), 132.5 (C-6), 135.8 (C-3), 137.5, 150.5 (C-2, -4), $167.5(\mathrm{C}=\mathrm{O})$; (found: $302.1167 . \mathrm{C}_{17} \mathrm{H}_{18} \mathrm{O}_{5}$ requires, 302.1154).

\section{Methyl 4-hydroxy-2,3-dimethoxy-6-methylbenzoate (16)}

A mixture of the acid-phenol (2.0 g, 9.42 mmoles), anhydrous potassium carbonate $(1.5 \mathrm{~g}, 10.85 \mathrm{mmoles})$ and dimethyl sulphate $(1.2 \mathrm{~g}, 9.51 \mathrm{mmoles})$ in dry acetone (50 $\mathrm{mL}$ ) was stirred overnight at room temperature under argon atmosphere. The mixture was poured into ice cold $2 \mathrm{M}$ hydrochloric acid $(80 \mathrm{~mL})$ and was extracted with diethyl ether $(3 \times 80 \mathrm{~mL})$. The combined organic layers were washed with water $(2 \times 50 \mathrm{~mL})$ and brine $(1 \times 50 \mathrm{~mL})$ and dried $\left(\mathrm{MgSO}_{4}\right)$. The organic mixture was filtered through a pad of silica and the silica was rinsed with a further 100 $\mathrm{mL}$ of diethyl ether-petrol 1:1. The solvent was removed under vacuum to give (16) as a solid (1.8 g, 84\%).

$\mathbf{R}_{\mathbf{f}} 0.48$ (petrol-diethyl ether 6:4); m.p. $77^{\circ} \mathrm{C}$; v(nujol mull) $/ \mathrm{cm}^{-1} 3399(\mathrm{OH}), 1710(\mathrm{C}=\mathrm{O}) ; \delta_{\mathrm{H}}\left(250 \mathrm{MHz} ; \mathrm{CDCl}_{3}\right.$; $\mathrm{J} / \mathrm{Hz}) 2.23$ (s, $\left.3 \mathrm{H}, \mathrm{ArCH}_{3}\right), 3.87\left(2 \mathrm{~s}, 6 \mathrm{H}, 2\right.$ x $\left.\mathrm{OCH}_{3}\right), 3.89$ (s, $\left.3 \mathrm{H}, \mathrm{OCH}_{3}\right) 6.12$ (s, $\left.1 \mathrm{H}, \mathrm{OH}\right), 6.55$ (s, $\left.1 \mathrm{H}, \mathrm{ArH}\right)$.

Methyl

4-hydroxy-5-iodo-2,3-dimethoxy-6-methylbenzoate (1)

1.0 M solution of iodine chloride in dry dichloromethane $(15.0 \mathrm{~mL})$ was added dropwise to a stirred solution of the methyl benzoate (16) (2.55 g, 11.3 mmoles) in dry dichloromethane $(50 \mathrm{~mL})$. The mixture was stirred for $5 \mathrm{~h}$, diluted with dichloromethane $(100 \mathrm{~mL})$ and washed with aqueous $\mathrm{Na}_{2} \mathrm{~S}_{2} \mathrm{O}_{3}(2 \times 30 \mathrm{~mL})$, and water $(1 \times 30 \mathrm{~mL})$. The organic layer was dried $\left(\mathrm{MgSO}_{4}\right)$ and the solvent evaporated. The residue was dissolved in petrol-ethyl acetate 1:2 (100 mL), filtered over a short column of silica gel and washed with petrol-ethyl acetate 1:2 (100 mL). The solvent was evaporated and the residue recrystallized from toluene-petrol to afford (1) as a white crystalline solid (2.56 $\mathrm{g}, 64 \%$ ). The solvent of the filtrate was removed and the residue purified by column chromatography to give a further $(0.80 \mathrm{~g}, 20 \%)$ of the iodo methyl ester.

$\mathbf{R}_{\mathbf{f}} 0.28$ (petrol-diethyl ether 6:4); m.p. $137-138{ }^{\circ} \mathrm{C}$; $\delta_{\mathrm{H}}\left(250 \mathrm{MHz} ; \mathrm{CDCl}_{3} ; \mathrm{J} / \mathrm{Hz}\right) 2.36\left(\mathrm{~s}, 3 \mathrm{H}, \mathrm{ArCH}_{3}\right), 3.88$, $3.91,3.91\left(3 \mathrm{~s}, 3\right.$ × $\left.3 \mathrm{H}, 2 \times \mathrm{OCH}_{3}, \mathrm{COOCH}_{3}\right), 6.38(\mathrm{~s}, 1 \mathrm{H}$, $\mathrm{OH}) ; \delta_{\mathrm{C}}\left(62.9 \mathrm{MHz} ; \mathrm{CDCl}_{3}\right) 25.2\left(\mathrm{ArCH}_{3}\right), 52.4\left(\mathrm{CO}_{2} \mathrm{Me}\right)$, 61.0, 61.4 (2 $\left.\mathrm{x} \mathrm{OCH}_{3}\right), 84.0(\mathrm{C}-5), 121.8(\mathrm{C}-1), 134.1,136.6$ (C-3, -6), 149.6, 150.5 (C-2, -4), $167.7(\mathrm{C}=\mathrm{O})$; (found: $\mathrm{C}$, 37.66; $\mathrm{H}, 3.73 ; \mathrm{I}, 36.88 . \mathrm{C}_{11} \mathrm{H}_{13} \mathrm{O}_{5} \mathrm{I}$ requires, $\mathrm{C}, 37.52 ; \mathrm{H}$, 3.72; I, 36.04).

\section{4-Hydroxy-5-iodo-2,3-dimethoxy-6-methylbenzoic acid} (17)

A solution of the iodo methyl ester (1) $(0.4 \mathrm{~g}, 1.136$ mmoles) in $2.5 \mathrm{M}$ aqueous sodium hydroxide $(20 \mathrm{~mL})$ was refluxed for $3 \mathrm{~h}$. The reaction mixture was poured into ice-cold $2 \mathrm{M}$ hydrochloric acid $(50 \mathrm{~mL})$ and then extracted with diethyl ether $(3 \times 50 \mathrm{~mL})$. The combined organic layers were washed with water $(2 \times 50 \mathrm{~mL})$ and dried $\left(\mathrm{MgSO}_{4}\right)$. The solvent was evaporated under vacuum and the residue was left under high vacuum for $6 \mathrm{~h}$ to give the free acid as a white crystalline solid $(0.35 \mathrm{~g}, 91 \%)$.

$\mathbf{R}_{\mathbf{f}} 0.10$ (petrol-diethyl ether 6:4); m.p. $63{ }^{\circ} \mathrm{C} ; \delta_{\mathrm{H}}(250$ $\mathrm{MHz} ; \mathrm{CD}_{3} \mathrm{CN}$; J/Hz) 2.55 (s, $\left.3 \mathrm{H}, \mathrm{ArCH}_{3}\right), 3.95,3.96$ (2s, $\left.2 \times 3 \mathrm{H}, 2 \times \mathrm{OCH}_{3}\right), 6.5$ (broad s, $\left.1 \mathrm{H}, \mathrm{OH}\right)$.

Benzyl

5-iodo-4-hydroxy-2,3-dimethoxy-6-methylbenzoate (2)

Benzyl bromide (0.2 g, 1.17 mmoles) was added by pipette to a stirred mixture of the iodo-carboxylic acid (17) (0.34 g, $1.01 \mathrm{mmoles})$ and anhydrous potassium carbonate $(0.2 \mathrm{~g}, 1.45 \mathrm{mmoles})$ in dry acetone $(20 \mathrm{~mL})$ under argon atmosphere. The mixture was stirred overnight and was poured into ice-cold $2 \mathrm{M}$ hydrochloric acid $(50 \mathrm{~mL})$. The mixture was extracted with diethyl ether $(4 \times 50 \mathrm{~mL})$, dried $\left(\mathrm{MgSO}_{4}\right)$, evaporated to dryness under vacuum and the residue purified by column chromatography eluting with petrol-diethyl ether 7:3 to give the iodo benzyl ester as an oil $(0.3 \mathrm{~g}, 70 \%)$.

$\mathbf{R}_{\mathbf{f}} 0.36$ (petrol-diethyl ether 6:4); ); $\delta_{\mathrm{H}}(250 \mathrm{MHz}$; $\left.\mathrm{CDCl}_{3} ; \mathrm{J} / \mathrm{Hz}\right) 2.32\left(\mathrm{~s}, 3 \mathrm{H}, \mathrm{ArCH}_{3}\right), 3.78,3.88(2 \mathrm{~s}, 2$ × $3 \mathrm{H}$, $\left.2 \times \mathrm{OCH}_{3}\right), 5.36\left(\mathrm{~s}, 2 \mathrm{H}, \mathrm{CH}_{2}, \mathrm{Bn}\right), 6.43$ (s, $\left.1 \mathrm{H}, \mathrm{OH}\right)$, 7.34-7.45 (m, $5 \mathrm{H}, \mathrm{ArH}, \mathrm{Bn}) ; \delta_{\mathrm{C}}\left(62.9 \mathrm{MHz} ; \mathrm{CDCl}_{3}\right) 25.1$ $\left(\mathrm{ArCH}_{3}\right), 61.0,61.2\left(2 \times \mathrm{OCH}_{3}\right), 67.2\left(\mathrm{CO}_{2} \mathrm{CH}_{2}\right), 84.0$ (C-5), 121.7 (C-1), 128.2, 128.4, 128.5 (Bn, o, m, p), 134.1, 135.4 (C-2, -6), 136.5 (C-1, Bn), 149.6, 150.4 (C-2, -4), $(\mathrm{C}=\mathrm{O})$; (found: 428.0109. $\mathrm{C}_{17} \mathrm{H}_{17} \mathrm{O}_{5} \mathrm{I}$ requires, 428.0121). 


\section{Results and Discussion}

The benzyl group is easily removed by hydrogenation in the presence of palladium on carbon. We envisaged the synthesis of benzyl 4-hydroxy-5-iodo- 2,3-dimethoxy-6methylbenzoate (2) as a potential intermediate for the synthesis of calicheamicin $\gamma_{1}{ }^{\mathrm{I}}$.

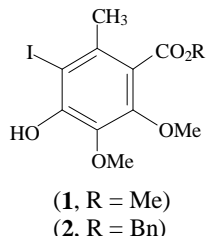

Orsellinic acid (6) was prepared in three steps in high yield from the readily available 3,5-dimethoxytoluene (3) following the literature procedure ${ }^{4}$.

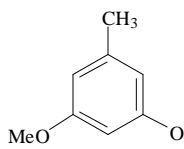

(3)

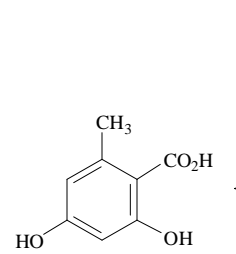

(6)

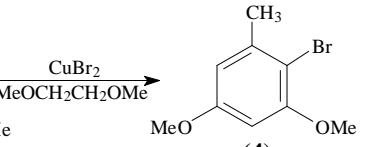

(4)

1) $\mathrm{BuLi}, \mathrm{Et}_{2} \mathrm{O}$ 2) $\mathrm{CO}_{2}$

$\mathrm{CH}_{3}$

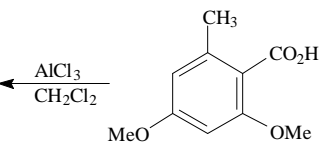

(5)
Benzylation of orsellinic acid with benzyl bromide in the presence of anhydrous potassium carbonate in dry acetone under reflux gave the di (7) and tribenzylated (8) adducts in $42 \%$ and $58 \%$ yield respectively.

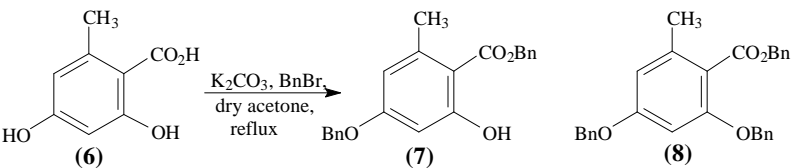

The tribenzylated compound (8) can be converted quantitatively back into starting material (6) by hydrogenation in the presence of palladium on carbon.

Benzyl 4-benzyloxy-2-hydroxy-6-methylbenzoate (7) was selectively formylated with dichloromethyl methyl ether and titanium tetrachloride in the ortho position in $89 \%$ yield ${ }^{5}$. The aldehyde (9) was oxidised to the corresponding catechol $(\mathbf{1 0})$ with hydrogen peroxide $(\mathbf{9 6 \%} \text { yield })^{6,7}$. Methylation of (10) with dimethyl sulphate gave the dimethoxy compound (11) in 83\% yield.

The two benzyl groups were removed by catalytic hydrogenation in quantitative yield. Compound (12) was then monobenzylated with benzyl bromide at room temperature in the presence of the free phenol. Nevertheless attempts to iodinate the benzyl esters (compounds $\mathbf{1 1}$ and 13) with iodine chloride to produce compounds (14 and 15) failed.
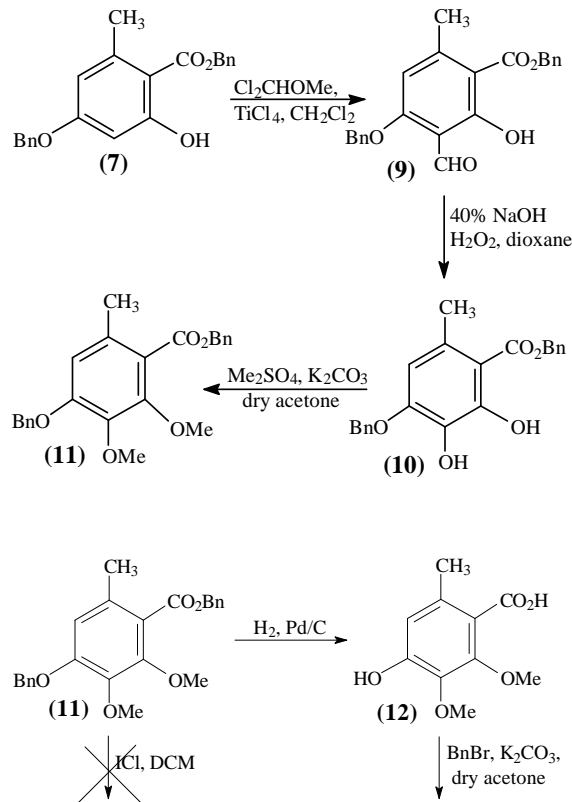

(12) $\mathrm{OMe}$<smiles>CCCCCC(=O)c1c(C)c(I)c(OC)c(OC)c1OC</smiles>

14, R = Bn) $(15, \mathbf{R}=\mathbf{H})$

Methylation with dimethyl sulphate in dry acetone in the presence of anhydrous potassium carbonate of (12) gave the methyl ester (16). The literature procedure was followed to iodinate and hydrolyse the methyl ester (16) to produce $(\mathbf{1 7})^{8}$. Finally, compound (17) was benzylated with benzyl bromide in dry acetone in the presence of potassium carbonate in $70 \%$ yield to give the title compound (2).

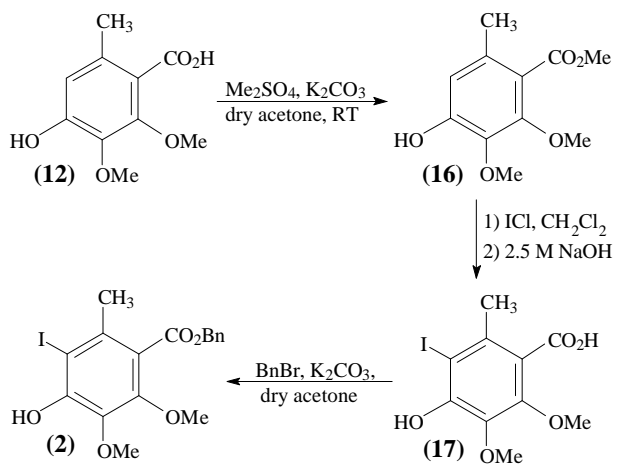

\section{Acknowledgements}

E.S. de Alvarenga thanks the Yamanouchi Research Institute for a Research Fellowship. 


\section{References}

1. Nicolaou, K.C.; Groneberg, R.D.; Stylianides, N.A.; Miyazaki, T. J. Chem. Soc., Chem. Commun. 1990, 1275.

2. Groneberg, R.D.; Miyazaki, T.; Stylianides, N.A.; Schulze, T.J.; Stahl, W.; Schreiner, E.P.; Suzuki, T.; Iwabuchi, Y.; Smith, A.L.; Nicolaou, K.C. J. Am. Chem. Soc. 1993, 115, 7593; Nicolaou, K.C.; Ebata, T.; Stylianides, N.A.; Groneberg, R.D.; Carrol, P.J. Angew. Chem. Int. Ed. Engl. 1988, 27, 1097.
3.Perrin, D.D.; Armarego, W.L.F. In Purification of Laboratory Chemicals, Pergamon Press, 3rd Ed., Oxford, UK, 1988.

4.Evans, G.E.; Staunton, J. J. Chem. Soc. Perkin Trans 1 1988, 755.

5.Cresp, T.M.; Sargent, M.V.; Elix, J.A.; Murphy, D.P.H. J. Chem. Soc. Perkin I 1973, 340.

6. Hocking, M.B. Can. J. Chem. 1973, 51, 2384.

7.Hocking, M.B.; Bhandari, K.; Shell, B.; Smyth, T.A. J. Org. Chem. 1982, 47, 4208.

8. Laak, K.V.; Scharf, H.D. Tetrahedron 1989, 45, 5511.

Received: April 30, 1998 